\title{
Preliminary estimate of primary production by phytoplankton in Marennes-Oléron Bay, France
}

\author{
Caroline Struski ${ }^{\mathrm{a}, *}$ and Cédric Bacher ${ }^{\mathrm{b}}$ \\ ${ }^{a}$ Centre de Recherche sur les Ecosystèmes Marins et Aquacoles (CREMA/UMR 10 CNRS- \\ IFREMER), B.P. 5, F-17137 L' Houmeau, France \\ ${ }^{\mathrm{b}}$ IFREMER, Z.I. Pointe du Diable, B.P. 70, F-29280 Plouzané, France \\ *: Corresponding author : mailto:cstruski@ifremer.fr
}

\begin{abstract}
:
The macrotidal bay of Marennes-Oléron is the most important French site for shellfish production (oysters and mussels); yet the primary productivity of the phytoplankton compartment in this system is not well known. In this study, photosynthetic parameters were determined using $14 \mathrm{C}$ incubations of bottom and surface water samples, during fall, winter and summer (2001-2002), along a north-south transect in the bay. Estimates of primary productivity showed that water column primary production is light-limited in the bay and that a BZpIO type model can be applied. Spatial differences existed in the bay, with a more productive northern zone and less productive river area. With a water column primary production of $185 \mathrm{~g} \mathrm{C} \mathrm{m-2} \mathrm{yr-1,} \mathrm{Marennes-Oléron} \mathrm{Bay} \mathrm{lies} \mathrm{in} \mathrm{the} \mathrm{mean} \mathrm{range} \mathrm{for} \mathrm{phytoplankton}$ primary production capacity among European and North American estuaries.
\end{abstract}

Keywords: photosynthesis parameters; phytoplankton; turbidity; light limitation; tidal bay; $B Z_{\mathrm{p}} I_{0}$ model 


\section{Introduction}

The macrotidal bay of Marennes-Oléron on the French Atlantic coast (Figure 1) is the most important site for commercial shellfish production in France, with a stock of 81,000 tons of oysters and mussels and an annual production of 40,000 tons,. The large scale of shellfish culture in the bay has led to studies on the carrying capacity of the ecosystem (Bacher, 1989; Bacher et al., 2000). However, as is the case for many intertidal estuaries, the factors controlling primary production in the bay are not well known. The Charente River represents the major source of nutrients entering the system (Ravail et al., 1988) but Marennes-Oléron Bay is also influenced by the Gironde plume (Boutier et al., 2000), which enters through the northern strait of the basin. The bay waters are often turbid because of sediment resuspension from extensive intertidal mudflats that make up half of the total surface area $\left(180 \mathrm{~km}^{2}\right)$.

Phytoplankton in the bay waters are both of pelagic and benthic origin. Oceanic waters transport pelagic phytoplankton to the bay, and microphytobenthos can become resuspended from the intertidal mudflats (Riera and Richard, 1996). Physical forcing, exchanges and mixing between water masses could create variability in photosynthetic parameters on a time scale of hours (Lucas et al., 1999; MacIntyre et al., 2000), days (due either to circadian or tidal variation) (Sournia, 1974, Demers and Legendre, 1979; Fréchette and Legendre, 1982; Brunet and Lizon, 2003), and/or seasons (Harrison and Platt, 1980). Spatial and temporal heterogeneities could also contribute to variability in parameter estimates (Platt, 1975; MacCaull and Platt, 1977; Forbes et al., 1986 ). Previous studies in Marennes-Oléron Bay have measured the variability of photosynthetic parameters for the microphytobenthos on the mudflats (Blanchard and Cariou-Le Gall, 1994) and for phytoplankton in the mouth of the Charente River (Ravail, 1993), but not throughout the bay. As a consequence, model estimates of primary production for Marennes-Oléron Bay have relied on literature values for calibration (Raillard and Ménesguen, 1994; Bacher et al., 1998).

The objectives of the present study were: (1) to calibrate a model of primary production in the water column by measuring photosynthetic parameters along a north-south transect in the bay during fall, winter and summer, (2) to determine which factor(s) limit primary production, and (3a) to compare the water column primary production with microphytobenthic primary production in Marennes-Oléron Bay and (3b) with other intertidal ecosystems.

\section{Materials and methods}

\subsection{Site description and water sampling}

Roughly triangular in form, the broad northern end of Marennes-Oléron Bay, which is open to the French Atlantic Ocean, tapers down to a narrow channel in the south. There is a residual current between the northern and southern portions of the bay (Dechambenoy et al., 1977). Two rivers discharge into the bay, the Charente River in the north (mean annual input: $100 \mathrm{~m}^{3} \mathrm{~s}^{-1}$ ), and the Seudre River in the south (mean annual input: $10 \mathrm{~m}^{3} \mathrm{~s}^{-1}$, (data from Direction Départementale de l'Environnement, http://www.equipement.gouv.fr)).

A water quality monitoring network was established in 1977 for the bay (the RAZLEC database, Soletchnik et al., 1998). Five points in this network, sites 1, 2, 3', 5 and 6 (Figure 1), were selected for this study as being representative of different hydrological conditions (Héral et al., 1983, 1984). Site 1 is located in the north of the bay and is influenced by oceanic water. Sites 2 and 5 are located in the mouths of the Charente and Seudre rivers, respectively. Site 3' is located in the centre of the bay where waters from the northern and southern portions of the bay mix. Site 6 , in the south of the bay, can be influenced by oceanic waters depending on the tidal regime. This study was based on the sites 1,2, 5 and 6 , with two additional sites in the central channel, 3 and 4, replacing site 3 '.

In October 2001 and in March and June 2002, fall, winter and summer respectively, water sample were collected during spring tides from the six sites, providing an approximately 
north-south transect of Marennes-Oléron Bay (Figure 1). The six sites were sampled at 2 hours intervals during daylight hours, for diel production experiments and for environmental parameter measurements. For primary production estimates, two types of water samples were collected at each site using Niskin bottles: (1) near-surface, at less than 1 meter deep, and (2) near-bottom, at less than one meter above the bottom. All water samples were filtered onboard with Whatman GF/F glass-fibre filters. Other survey cruises were conducted to measure light attenuation profiles at the sites, within 15 days of the water sampling cruises.

\subsection{Field Measurements}

Salinity and temperature were measured with a LF196 conductivity meter (WTW, USA), while photosynthetically available radiation (PAR) was measured simultaneously in the water column and onboard the boat, using a PNF-300A profiler (Biospherical Instruments, USA) to determine light attenuation. An exponential model was adjusted based on the relative available light recorded in the water column (PARwater/PARsurface, \%). Water samples were collected to measure total particulate matter (TPM, mg $\mathrm{L}^{-1}$ ) and the power relationship between the attenuation coefficent $\left(\mathrm{k}, \mathrm{m}^{-1}\right)$ and TPM was corrected accordingly. A power function was used to fit relation between the coefficient of light attenuation $\left(\mathrm{k}, \mathrm{m}^{-1}\right)$ and TPM.

\subsection{Laboratory Analyses}

Chlorophyll $a\left(\mathrm{Chl} a, \mu \mathrm{g} \mathrm{L}^{-1}\right)$ and pheophytin (Pheo, $\mu \mathrm{g} \mathrm{L}^{-1}$ ) were measured on triplicate water samples that had been filtered through Whatman GF/F glass-fibre filters and stored frozen until analysis. The samples were extracted in $90 \%$ acetone for $24 \mathrm{~h}$, and then analysed fluorometrically (Model 10-AU fluorimeter, Turner Designs, USA) both before and after addition of $80 \mu \mathrm{L}$ of $1 \mathrm{~N} \mathrm{HCl}$ (Aminot and Chaussepied, 1983).

Subsamples of the filtered seawater were also stored frozen and later used for nutrient analysis. Dissolved nutrients concentrations (urea, ammonium, nitrite, nitrate, phosphate and silicate, $\mu \mathrm{M}$ ) were determined using an autoanalyser (Skalar, Netherlands) according to the protocols of Strickland and Parsons (1972).

Water samples for particulate matter analyses were filtered through pre-combusted (500 ${ }^{\circ} \mathrm{C}$ for $3 \mathrm{~h}$ ) and pre-weighed Whatman GF/C glass-fibre filters and then rinsed with distilled water to remove the salts. The filters were dried for $24 \mathrm{~h}$ at $60{ }^{\circ} \mathrm{C}$ and re-weighed for the determination of TPM. Particulate inorganic matter (PIM, $\mathrm{mg} \mathrm{L}^{-1}$ ) was calculated from the mass of ash remaining after combustion of the filter at $500{ }^{\circ} \mathrm{C}$ for $3 \mathrm{~h}$. The particulate organic matter fraction (POM, mg L ${ }^{-1}$ ) was estimated from the difference between TPM and PIM.

Primary production measurements were made using the incubation system described in Lewis and Smith (1983), with 24 individual incubators. Scalar irradiance in each incubator was measured with a QSL-100 irradiance sensor (Biospherical Instrument, USA) connected to a $4 \pi$ quantum sensor. During the incubation, seawater samples were exposed to a range of PAR (wavelength range from about $400-700 \mathrm{~nm}$ ) from 0 to about $1300 \mu \mathrm{E} \mathrm{m} \mathrm{m}^{-2} \mathrm{~s}^{-1}$. Each incubator chamber contained one five-mL aliquot of the light-exposed seawater in a $20 \mathrm{~mL}$ scintillation vial which was inoculated with $100 \mu \mathrm{L}$ of ${ }^{14} \mathrm{C}$-bicarbonate solution $\left(20 \mu \mathrm{Ci} \mathrm{mL}{ }^{-1}\right.$ specific activity) and then incubated for $20 \mathrm{~min}$. The incubation temperature was maintained using a circulating water bath at the ambient water temperature of each sample site and date (range: 8 to $20^{\circ} \mathrm{C}$ ).

After incubation was complete, all biological reactions were stopped by the addition of $250 \mu \mathrm{L}$ of buffered formalin. Two dark and two time-zero formalin-killed controls were processed using the same procedures. The total added activity was measured by dispensing $100 \mu \mathrm{L}$ of ${ }^{14} \mathrm{C}$-bicarbonate solution into $10 \mathrm{~mL}$ of scintillation cocktail (Insta-Gel Plus, Packard Bioscience, France) containing $250 \mu \mathrm{L}$ phenyl-ethylamine. The total dissolved $\mathrm{CO}_{2}$ was estimated by measuring the carbonate alkalinity (Parsons et al., 1984). Excess ${ }^{14} \mathrm{C}-$ 
bicarbonate was removed by adding $1 \mathrm{~mL}$ of $6 \mathrm{~N} \mathrm{HCl}$ and shaking for $2 \mathrm{~h}$, then adding $10 \mathrm{~mL}$ of scintillation cocktail to each vial. Radioactivity (in $\mathrm{dpm}$ ) was measured using a Packard Tri-carb 2100 liquid scintillation counter with the quenching correction applied. All photosynthetic rates were normalized to $\mathrm{Chl} a$.

The hyperbolic tangent function (Eq. 1) of Jassby and Platt (1976) was used to fit the experimental data:

$$
\mathrm{P}^{\mathrm{B}}=\mathrm{P}_{\max }^{\mathrm{B}} \cdot \tanh \left(\frac{\alpha^{\mathrm{B}} \cdot \mathrm{E}}{\mathrm{P}_{\mathrm{m}}^{\mathrm{B}}}\right)
$$

where $\mathrm{P}^{\mathrm{B}}\left(\mathrm{mgC} \mathrm{mgChl} a^{-1} \mathrm{~h}^{-1}\right)$ is the photosynthetic rate normalized to $\mathrm{Chl} a$ at the scalar irradiance $\mathrm{E}\left(\mu \mathrm{E} \mathrm{m}^{-2} \mathrm{~s}^{-1}\right), \mathrm{P}_{\max }^{\mathrm{B}}\left(\mathrm{mgC} \mathrm{mgChl} a^{-1} \mathrm{~h}^{-1}\right)$ is the maximum photosynthetic rate at saturating irradiance, and $\alpha^{\mathrm{B}}\left(\mathrm{mgC} \mathrm{mgChla}{ }^{-1} \mathrm{~h}^{-1}\left(\mu \mathrm{E} \mathrm{m}^{-2} \mathrm{~s}^{-1}\right)^{-1}\right)$ is the initial slope of the P-E curve at sub-saturating irradiance. Superscript ${ }^{B}$ indicates photosynthetic rates that are

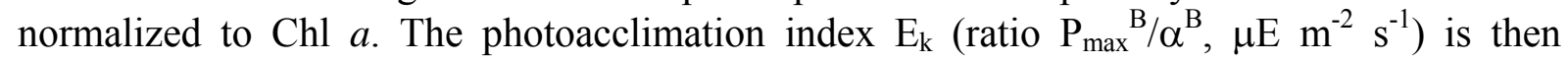
calculated. The mean irradiance in the water column $\mathrm{E}_{\mathrm{m}}$ is calculated from:

$$
\mathrm{E}_{\mathrm{m}}=\frac{\mathrm{E}_{0}}{\mathrm{k} \cdot \mathrm{z}_{\mathrm{m}}} \cdot\left(1-\mathrm{e}^{-\mathrm{k} \cdot \mathrm{z}_{\mathrm{m}}}\right)
$$

where $E_{0}$ is the incident irradiance, $k$ is the attenuation coefficient $\left(\mathrm{m}^{-1}\right)$ and $\mathrm{z}_{\mathrm{m}}$ is the depth of the water column. Hourly data for $\mathrm{E}_{0}$ were obtained from a Météo France weather monitoring station (http://www.meteofrance.com), located north of the bay, which can be reasonably assumed to represent conditions in the Marennes-Oléron Bay.

For photosynthetic parameters, ANOVAs were performed to compare sites and compare surface and bottom water type samples for each survey.

Models of primary production in the water column developed for Marennes-Oléron Bay were based on nutrient limitations (Raillard and Ménesguen, 1994). The definitions of nutrient limitations of Dortch and Whitledge (1992) were applied (DIN-limitation: DIN $<1$ $\mu \mathrm{M}$ and $\mathrm{DIN} / \mathrm{PO}_{4}{ }^{3-}<10$; P-limitation: $\mathrm{PO}_{4}{ }^{3-}<0.2 \mu \mathrm{M}$ and $\mathrm{DIN} / \mathrm{PO}_{4}{ }^{3-}>30$; Si-limitation: $\mathrm{Si}<2$ $\mu \mathrm{M}, \mathrm{Si} / \mathrm{DIN}<1$ and $\mathrm{Si} / \mathrm{PO}_{4}{ }^{3-}<3$ ). For uptake by phytoplankton in the turbid estuarine zone, the threshold of Fisher et al. (1988) could be also be applied. These authors considered that limiting nutrient conditions may exist when the in situ concentration of a nutrient is less than half the saturation constant (DIN: $2 \mu \mathrm{M}$; $\mathrm{PO}_{4}{ }^{3-}: 0.5 \mu \mathrm{M}$; Si: $5 \mu \mathrm{M}$ ). Nutrients limit primary production in the absence of light limitation defined by the $\mathrm{E}_{\mathrm{m}} / \mathrm{E}_{\mathrm{k}}$ ratio (Sakshaug et al., 1997; Tillmann et al., 2000).

\subsection{Primary production estimates}

For each sampling site and time, the local productivity in the water column was calculated by integrating photosynthetic rates over the water depth. The productivity at depth $\mathrm{z},(\mathrm{P}(\mathrm{z}, \mathrm{t})$; $\mathrm{mgC} \mathrm{m}^{-2} \mathrm{~h}^{-1}$ ), was calculated from the mean of the measured bottom and surface water photosynthetic parameters, $\mathrm{Chl} a$ concentration and the attenuation coefficient $(\mathrm{k})$ :

$$
\mathrm{P}(\mathrm{z}, \mathrm{t})=\operatorname{Chla}(\mathrm{t}) \cdot \mathrm{P}_{\mathrm{m}}^{\mathrm{B}}(\mathrm{t}) \cdot \tanh \left(\frac{\alpha^{\mathrm{B}}(\mathrm{t}) \cdot \mathrm{E}(\mathrm{z}, \mathrm{t})}{\mathrm{P}_{\mathrm{m}}^{\mathrm{B}}(\mathrm{t})}\right)
$$

where the irradiance at depth $\mathrm{z}$ is:

$$
E(z, t)=E_{0}(t) \cdot e^{-k(t) \cdot z}
$$

The profile $\mathrm{P}(\mathrm{z}, \mathrm{t})$ was then integrated over depth to estimate the productivity per unit area, $\mathrm{P}(\mathrm{t})\left(\mathrm{mgC} \mathrm{m} \mathrm{m}^{-2} \mathrm{~h}^{-1}\right)$ : 


$$
\mathrm{P}(\mathrm{t})=\sum_{\mathrm{z}=0}^{\mathrm{z}=\mathrm{z}_{\max }} \mathrm{P}(\mathrm{z}, \mathrm{t}) \cdot \Delta \mathrm{z}
$$

with integration step of $\Delta \mathrm{z}=0.05 \mathrm{~m}$.

Using the RAZLEC database, the monthly means of TPM and Chl $a$ were calculated for sites 1, 2, 5 and 6 in 2001 and 2002. Sampling sites 3 and 4 were not part of the RAZLEC database therefore an intermediate site was substituted, site 3' (Fig. 1). Using the mean $\mathrm{P}_{\max }{ }^{B}$ and $\alpha^{\mathrm{B}}$ values, hourly data for $\mathrm{E}_{0}$ during 2001 and 2002, and calculated water depths based on the tide equation, estimates of daily, monthly and annual production were made for these 5 sites in 2001 and 2002.

Using the site estimates, primary production of the entire bay was computed based on a $200 \mathrm{~m} \times 200 \mathrm{~m}$ bathymetric grid. Eq. (3) was spatialized (becoming $\mathrm{P}(\mathrm{x}, \mathrm{y}, \mathrm{z}, \mathrm{t})$ ) and was then integrated over depth to estimate the productivity of the bay per unit area, $\mathrm{P}(\mathrm{x}, \mathrm{y}, \mathrm{t})$. Daily and annual estimates of total production were calculated by integrating successive values of hourly productivity per unit area.

A sensitivity analysis was done using the minimum and maximum values of the photosynthetic parameters.

Using data from the RAZLEC database for site 3', all the monthly minima and maxima for TPM and Chl $a$ were used to construct a series of hypothetical extreme conditions. New estimates for primary production were then calculated based on these scenarios.

\section{Results}

\subsection{Environmental parameters}

Water temperatures were warmer in fall and summer, from $17{ }^{\circ} \mathrm{C}$ up to $20^{\circ} \mathrm{C}$, compared to $8{ }^{\circ} \mathrm{C}$ during the winter sampling. Freshwater inflow, from the Charente River to the northern portion of Marennes-Oléron Bay near site 2, varied (in approximate figures) from $25 \mathrm{~m}^{3} \mathrm{~s}^{-1}$ during October 2001, to around $40 \mathrm{~m}^{3} \mathrm{~s}^{-1}$ in early February 2001, peaking at 100 $\mathrm{m}^{3} \mathrm{~s}^{-1}$ at the beginning of March, then decreasing to $50 \mathrm{~m}^{3} \mathrm{~s}^{-1}$ in mid-June and continuing down to $15 \mathrm{~m}^{3} \mathrm{~s}^{-1}$ at the beginning of July. The salinity was about 33 at all sites, except in site 2 where it ranged from 9 and 33 .

At site 2, Chl $a$ ranged between 2 and $6 \mu \mathrm{g} \mathrm{L}^{-1}$ in fall, while in winter and summer varied from 2 to $14 \mu \mathrm{g} \mathrm{L}^{-1}$. The concentration range for Pheo at this site was between 5 and $30 \mu \mathrm{g}$ $\mathrm{L}^{-1}$ (maximum of $100 \mu \mathrm{g} \mathrm{L}^{-1}$ near low tide at 11:00 UT during the fall sampling). For the other sites, the concentration range of Chl $a$ was lower, around 1 to $3 \mu \mathrm{g} \mathrm{L}^{-1}$, in fall and winter, increasing to 3 to $6 \mu \mathrm{g} \mathrm{L}^{-1}$ in summer (Fig. 2A). The concentration of Pheo ranged between 1 and $8 \mu \mathrm{g} \mathrm{L}^{-1}$ over the whole studied period. Pheopigments are stable relative to $\mathrm{Chl} a$ (data not shown) and therefore the $\mathrm{Chl} a /(\mathrm{Pheo}+\mathrm{Chl} a)$ ratio depended on variations in Chl $a$.

TPM ranged between 50 and $1500 \mathrm{mg} \mathrm{L}^{-1}$ at site 2, with an absolut maximum of 3500 $\mathrm{mg} \mathrm{L}^{-1}$ near low tide in fall (data not shown). For all other sites, TPM varied between 20 and $110 \mathrm{mg} \mathrm{L}^{-1}$ in fall, between 25 and $225 \mathrm{mg} \mathrm{L}^{-1}$ in winter and between 10 and $80 \mathrm{mg} \mathrm{L}^{-1}$ in summer. There was a large difference between surface water samples and bottom water samples for some sites, such as sites 2 and 5. Variations in PIM were similar to those of TPM. PIM/TPM ratio ranged between $85 \%$ and $95 \%$ in fall, between $90 \%$ and $95 \%$ in winter and between $70 \%$ and $95 \%$ in summer. Differences between sites were larger in winter.

In fall, except for sites 2 and 4, the dissolved inorganic nitrogen (DIN) ranged between 8 and $17 \mu \mathrm{M}$; values for sites 2 and 4 ranged between 10 and $110 \mu \mathrm{M}$ and there were significant differences between surface and bottom water samples (data not shown). In 
winter, again with the exception of site 2 , DIN increased to between 17 and $40 \mu \mathrm{M}$, with a maximum of $90 \mu \mathrm{M}$ at site 3 . In winter at site 2, DIN ranged between 35 and $120 \mu \mathrm{M}$. During summer, DIN ranged between 5 and $25 \mu \mathrm{M}$ and lower values were measured at site 1 . The maximum concentration of $78 \mu \mathrm{M}$ was determined at low tide at site 2 in summer.

Silicate $\left(\mathrm{Si}(\mathrm{OH})_{4}\right)$ concentrations ranged from 8 to $95 \mu \mathrm{M}$. Most $\mathrm{Si}(\mathrm{OH})_{4} / \mathrm{DIN}$ ratios were close to 1 during fall and winter, and around 0.6 in summer at all the sites (data not shown).

Dissolved phosphate $\left(\mathrm{PO}^{3-}\right.$ ) concentrations ranged between 0.2 and $0.8 \mu \mathrm{M}$ in fall with the maximum, $1.6 \mu \mathrm{M}$, recorded at site 2 at low tide. In winter, $\mathrm{PO}^{3-}{ }_{4}$ increased between 10 and $25 \mu \mathrm{M}$, except for site 2 which reached $100 \mu \mathrm{M}$ around low tide. In summer, $\mathrm{PO}_{4}^{3-}$ decreased to between 0.01 and $0.5 \mu \mathrm{M}$, again with the maximum value, $2 \mu \mathrm{M}$, being measured at site 2 during low tide (Fig. 2B).

Positive and significant correlations (Spearman's test $\mathrm{p}<0.05$ ) were found between $\mathrm{Pheo} / \mathrm{TPM} / \mathrm{POM}$ and $\mathrm{PO}_{4} / \mathrm{Si}(\mathrm{OH})_{4}$. Negative and significant $(\mathrm{p}<0.05)$ correlations existed between $\mathrm{Chl} a / \mathrm{PO}_{4}$ and $\mathrm{Chl} a / \mathrm{Si}(\mathrm{OH})_{4}$.

\subsection{Photosynthetic parameters}

Only good fits of Eq. 1 (Fig. 3) on experimental data were kept (F-test, p $<0.005$, $\mathrm{n}=123$ ). Comparison of the non-linear curves showed differences between surface and bottom water photosynthetic parameters for some samples, for example, at site 6 (Fig. 4A and $\mathrm{B})$.

The maximum photosynthetic rate, $\mathrm{P}_{\max }{ }^{\mathrm{B}}$ (Fig. 4A), ranged between 5.12 and $13.53 \mathrm{mgC}$ mgChla $a^{-1} \mathrm{~h}^{-1}$ (mean: $9.07 \pm 1.58 \mathrm{mgC} \mathrm{mgChl}^{-1} \mathrm{~h}^{-1}$ ). The value for $\alpha^{\mathrm{B}}$ (Fig. 4B) ranged between 0.011 and $0.066 \mathrm{mgC} \mathrm{mgChla}{ }^{-1} \mathrm{~h}^{-1}\left(\mu \mathrm{E} \mathrm{m}^{-2} \mathrm{~s}^{-1}\right)^{-1}$ (mean: $0.025 \pm 0.008 \mathrm{mgC}$

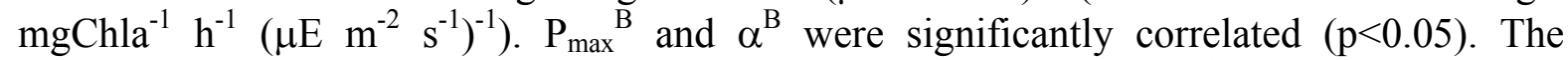
photoacclimation index, $\mathrm{E}_{\mathrm{k}}$, ranged between 181.68 and $772.66 \mu \mathrm{E} \mathrm{m}^{-2} \mathrm{~s}^{-1}$ (mean: $390.38 \pm$ $\left.106.12 \mu \mathrm{E} \mathrm{m}^{-2} \mathrm{~s}^{-1}\right)$.

While some significant differences (one-way ANOVA, $\mathrm{p}<0.05$ ) existed between surfacebottom pairs at each site, there were no sites or sample types that were characterised as significantly different under all conditions.

\subsection{Relationship between $k$ and TPM}

The regression equation was $\left(\mathrm{R}^{2}=0.73, \mathrm{n}=114\right)$, therefore

$$
\mathrm{k}=0.154 \cdot \mathrm{TPM}^{0.66}
$$

Using Eq. 6 with TPM values recorded during the surveys, $\mathrm{k}$ ranged between 0.6 and $36.1 \mathrm{~m}^{-1}$. The maximum value corresponded to a light level of $1 \%$ at $0.12 \mathrm{~m}$. Values of $\mathrm{k}$ were highest at site 2 and in bottom samples. Lowest values for $\mathrm{k}$ were estimated from surface water samples collected at sites 1 and 6 (Fig. 2C).

\subsection{Limitation of primary production in the bay}

Applying the definitions of Dortch and Whitledge (1992), neither DIN or Si were limiting factors for primary production during the sampling periods. However, in summer, phosphorus was limiting. While considering the thresholds defined by to Fisher et al. (1988), there was also no limitation for DIN, but phosphate was limiting in summer at all the sites and occasionally in fall. Silica was only limiting in summer in site 1. 
Apart from summer 2002 at sites 3, 4 and 5, the ratio $E_{m} / E_{k}$ were always less than 1 (Fig 4C). If the maximum photosynthetic rate, $\mathrm{P}_{\max } \mathrm{B}$, is never reached, then Equation (1) is reduced to a linear relationship. Equation (3) then becomes:

$$
\begin{aligned}
& \mathrm{P}(\mathrm{z}, \mathrm{t}) \approx \operatorname{Chla}(\mathrm{t}) \cdot \alpha^{\mathrm{B}}(\mathrm{t}) \cdot \mathrm{E}_{0}(\mathrm{t}) \cdot \int_{\mathrm{z}=0}^{\mathrm{z}=\mathrm{z} \max } \mathrm{e}^{-\mathrm{k} \cdot \mathrm{z}} \cdot \mathrm{dz} \\
& \mathrm{P}(\mathrm{z}, \mathrm{t}) \approx \operatorname{Chla}(\mathrm{t}) \cdot \alpha^{\mathrm{B}}(\mathrm{t}) \cdot \mathrm{E}_{0}(\mathrm{t}) \cdot\left[-\frac{\mathrm{e}-\mathrm{k}}{\mathrm{k}}\right]_{0}^{\mathrm{z} \max } \\
& \mathrm{P}(\mathrm{z}, \mathrm{t}) \approx \operatorname{Chla}(\mathrm{t}) \cdot \alpha^{\mathrm{B}}(\mathrm{t}) \cdot \mathrm{E}_{0}(\mathrm{t}) \cdot \frac{1}{\mathrm{k}} \cdot\left(-\mathrm{e}^{-\mathrm{k} \cdot \mathrm{z}_{\max }}+1\right)
\end{aligned}
$$

The expression $e^{-k \cdot z_{\max }}$ is equivalent to $e^{-\frac{4.61}{Z_{p}} \cdot z_{\max }}$, where $Z_{p}$ is the photic depth $(\mathrm{m})$. Since $Z_{\max }$ was greater than $Z_{p}$ in most cases, the exponential expression was very small with respect to 1. Expression (9) becomes:

$$
\mathrm{P}(\mathrm{t}) \approx \operatorname{Chla}(\mathrm{t}) \cdot \alpha^{\mathrm{B}}(\mathrm{t}) \cdot \mathrm{E}_{0}(\mathrm{t}) \cdot \frac{1}{\mathrm{k}}=\operatorname{Chla}(\mathrm{t}) \cdot \alpha^{\mathrm{B}}(\mathrm{t}) \cdot \mathrm{E}_{0}(\mathrm{t}) \cdot \frac{\mathrm{Z}_{\mathrm{p}}}{4.61}
$$

A significant correlation $\left(\mathrm{R}^{2}=0.92, \mathrm{p}<0.001\right)$ was found for the dataset:

$$
\operatorname{Prod}=0.005 \cdot \text { Chla } \cdot \mathrm{E}_{0} \cdot \mathrm{Z}_{\mathrm{p}}
$$

where 'Prod' is in $\mathrm{mgC} \mathrm{m} \mathrm{m}^{-2} \mathrm{~h}^{-1}$ and the algal biomass, Chl $a$, is in $\mathrm{mg} \mathrm{Chl} a \mathrm{~m}^{-3}$.

The value for $\alpha^{\mathrm{B}}$ calculated from this slope (Eq. 11) was $0.023 \mathrm{mgC} \mathrm{mgChla}{ }^{-1} \mathrm{~h}^{-1}(\mu \mathrm{E}$ $\left.\mathrm{m}^{-2} \mathrm{~s}^{-1}\right)^{-1}$, close to the previously estimated mean $\alpha^{\mathrm{B}}\left(0.025 \pm 0.008 \mathrm{mgC} \mathrm{mgChla}{ }^{-1} \mathrm{~h}^{-1}\right)$.

\subsection{Measured primary productivity and estimate of annual production}

The hourly productivity per unit area (Fig. 5) was less than $10 \mathrm{mgC} \mathrm{m}^{-2} \mathrm{~h}^{-1}$ in fall and winter at all sites. In summer, this productivity increased to a range between 10 and $50 \mathrm{mgC}$ $\mathrm{m}^{-2} \mathrm{~h}^{-1}$. A maximum of $120 \mathrm{mgC} \mathrm{m}^{-2} \mathrm{~h}^{-1}$ was estimated for site 6 . Excluding this value, the pattern of productivity was sinusoidal and the maximum was reached near midday. The daily coefficient of variation on hourly productivity estimates ranged between $11 \%$ and $119 \%$. Site coefficient of variation $(\mathrm{CV})$ ranged between $38 \%$ and $62 \%$. The seasonal $\mathrm{CV}$ ranged between $52 \%$ and $126 \%$ and the overall $\mathrm{CV}$ was $140 \%$ (Table 1).

The different TPM and Chl $a$ concentrations for the sites, as well as the variation in irradiance during 2001 and 2002, resulted in spatial and temporal variability in production estimates (Fig. 6A). The daily production estimates varied between $0.006 \mathrm{gC} \mathrm{m}^{-2} \mathrm{~d}^{-1}$ (site 2) and $3.6 \mathrm{gC} \mathrm{m}^{-2} \mathrm{~d}^{-1}$ (site 6). The monthly production (Fig. 6B) estimates were maximal between May and August, and could be as high as $62 \mathrm{gC} \mathrm{m}^{-2} \mathrm{month}^{-1}$ (site 1, summer 2002). In site 2, production was always the lowest with a maximum of $18 \mathrm{gC} \mathrm{m}^{-2} \mathrm{month}^{-1}$ in summer. During winter, all sites had lower production, between 0.5 and $0.8 \mathrm{gC} \mathrm{m}^{-2} \mathrm{month}^{-1}$. The annual production varied between 64 (site 2, 2001) and $301 \mathrm{gC} \mathrm{m}^{-2} \mathrm{yr}^{-1}$ (site 1, 2002).

The annual production in Marennes-Oléron Bay was estimated at $185 \mathrm{gC} \mathrm{m}^{-2} \mathrm{yr}^{-1}$. Using minimum and maximum values of $\mathrm{P}_{\max }{ }^{\mathrm{B}}$ and $\alpha^{\mathrm{B}}$, the annual production was calculated as ranging between 11.5 and $55.6 \mathrm{gC} \mathrm{m}^{-2} \mathrm{yr}^{-1}$. Using the mean $\alpha^{\mathrm{B}}, 50 \%$ of the variation in the 
mean $\mathrm{P}_{\text {max }}^{\mathrm{B}}$ created a variance of $21.4 \%$ in the mean production. Using the mean value for $\mathrm{P}^{\mathrm{B}}{ }_{\max }, 50 \%$ of the variation in the mean $\alpha^{\mathrm{B}}$ produced a variance of $29.5 \%$. Assuming that the photosynthetic parameters were the same for site 3', scenarios for maximum and minimum conditions ( $\mathrm{Chl} a$ minimum and TPM maximum, and the inverse) were created and produced an estimate of between 65 and $330 \mathrm{gC} \mathrm{m}^{-2} \mathrm{yr}^{-1}$ for this site

\section{Discussion}

\subsection{Site comparisons}

Marennes-Oléron Bay is directly influenced by Charente River freshwater discharge. Thus, site 2, which was situated at the mouth of Charente River, shows the effect of river discharges on dissolved nutrients, such as orthophosphates, in this part of the bay. Apart from the high phosphate values $(>10 \mu \mathrm{M})$ measured in winter at site 1 , the pigment, TPM and nutrient values were within the range of values typically recorded in Marennes-Oléron Bay (RAZLEC database, Soletchnik et al., 1988). Changes in freshwater inputs, wind-driven mixing, and different tidal coefficients $(110,110$ and 85, in the fall, winter and summer surveys respectively) could explain some of the observed variability. Low ratios of $\mathrm{Chl} a /(\mathrm{Pheo}+\mathrm{Chl} a)(<1)$ calculated in fall and winter suggested that a large part of the micro-algal pigments were detritus.

There were differences in the production estimates between 2001 and 2002. For the most oceanic site (site 1), the water was less turbid and richer in Chl $a$ and production estimates were higher. In the mouth of the Charente River, despite the source of nutrients, light limitation was more important and the estimated production was low relative to other locations. The spatial-temporal variability of primary productivity of different parts of Marennes-Oléron Bay shows its heterogeneity, between $30 \%$ and $130 \%$, suggesting that sites for shellfish culture could be re-evaluated in light of their proximity to areas of high primary production in the bay.

\subsection{Photosynthetic parameters and relationship between $k$ and TPM}

Photosynthetic parameters are correlated with temperature, light or nutrients (Geider et al., 1997) and sometimes with cell size and species composition (Harrison and Platt, 1980). Variability is circadian, with minima at dawn and sunset and the maximum at noon (Sournia, 1974); moreover, tides can interfere with these circadian rhythms (Demers and Legendre, 1979). The values determined for phytoplanktonic photosynthetic parameters, $P_{\max }{ }^{B}$ and $\alpha^{B}$ are within the range of those reported for other estuarine and littoral systems (Côté and Platt, 1983; Pennock and Sharp, 1986; Ravail-Legrand, 1993; Kromkamp and Peene, 1995; Cabeçadas, 1999; Tillmann et al., 2000; Shaw and Purdie, 2001).

$\mathrm{E}_{\mathrm{k}}$ is a convenient indicator of phytoplankton photoacclimation state (Sakshaug et al., 1997); thus, the high $E_{k}$ values found for the Marennes-Oléron Bay phytoplankton community suggests its acclimation to high light intensities, in spite of the mean low irradiance levels prevailing in the turbid water column. High $\mathrm{E}_{\mathrm{k}}$ values are associated with phytoplankton adapted to surface or near-surface conditions (Gallegos and Platt, 1985; Mallin and Pearl, 1992) and may be linked, in these samples, to the presence of recently resuspended microphytobenthos not yet adapted to the lower light conditions of the water column. $\mathrm{E}_{\mathrm{k}}$ values for microphytobenthos typically ranges between 150 and $900 \mu \mathrm{E} \mathrm{m} \mathrm{m}^{-2} \mathrm{~s}^{-1}$ (Blanchard and Montagna, 1992; Barranguet et al., 1998; Hartig et al., 1998; Wolfstein et al., 2000) and values between 370 and $650 \mu \mathrm{E} \mathrm{m}^{-2} \mathrm{~s}^{-1}$ have been reported for microphytobenthos Marennes-Oléron Bay intertidal mudflats (Blanchard and Cariou-Le Gall, 1994). The high $\mathrm{E}_{\mathrm{k}}$ indicates that the microphytobenthos on emerged intertidal mudflats are adapted to high light conditions. Shade adaptation occurs only after low light conditions become stable. 
When $E_{k}>>E_{m}$ the photosynthetic capacity of phytoplankton to use light is greater than the available light in the water column and the ratio $\mathrm{Em} / \mathrm{Ek}<1$ then there are light limiting conditions. As it was observed on many occasions during this study, the Em/Ek (Fig. 4C) was usually less than 1 . Light saturating conditions $(E m / E k \geq 1)$ were occasionally recorded in summer in the center (sites 3 and 4) and in the south of the bay (site 6).

The relationship between $\mathrm{k}$ and TPM was close to that established by Ménesguen (1995) for the Seine Estuary, but lower than that reported by Cloern (1987) for San Francisco Bay.

\subsection{Light limitation and the $B Z_{p} I_{0}$ model}

The coefficient of attenuation in Marennes-Oléron Bay was highly variable, which is typical of estuarine waters. With a photic depth varying from 0.12 to $7.6 \mathrm{~m}$, MarennesOléron Bay is among the 26 most turbid estuaries (Cloern, 1987).

Since Cole and Cloern $(1984,1987)$ published their regressions, models of production as a function of phytoplankton biomass and light availability have been applied to nutrient-rich estuaries. Converting regression Eq.11 to the units $\left(\mathrm{mgC} \mathrm{m} \mathrm{m}^{-2}\right)$ used in the compilation dataset from Brush et al. (2002) yielded a $\mathrm{P}_{\mathrm{d}}=0.08 \cdot \mathrm{BZ}_{\mathrm{P}} \mathrm{I}_{0}+23.3\left(\mathrm{R}^{2}=0.90\right)$. As this $\mathrm{y}-$ intercept value suggested that there may be net production in the absence of Chl $a$ and/or light, the regression was forced through the origin (Brush et al., 2002), giving: $P_{d}=$ $0.10 \cdot \mathrm{BZ}_{\mathrm{P}} \mathrm{I}_{0}\left(\mathrm{R}^{2}=0.72\right)$. The determined slope is thus within the low range of their dataset which included small slopes for Delaware Bay (0.07 in non-summer and 0.23 in summer) and the Westerschelde Estuary (0.22), which are both very turbid systems. The steepest slope was reported for San Francisco Bay (0.82).

\subsection{Estimate of primary production}

The water column primary production in the Marennes-Oléron Bay of $185 \mathrm{gC} \mathrm{m}^{-2} \mathrm{yr}^{-1}$ is close to the mean of other primary production capacity estimates for European estuaries (Table 2). Annual phytoplankton primary production estimates of European estuaries and coastal areas (see compilation in Tillmann et al. 2000 and Table 2), ranged between $7 \mathrm{gC} \mathrm{m}^{-2}$ $\mathrm{yr}^{-1}$ (Inner Bristol Channel) and $550 \mathrm{gC} \mathrm{m}^{-2} \mathrm{yr}^{-1}$ (Oosterschelde) with a mean of $180 \mathrm{gC} \mathrm{m}^{-2}$ $\mathrm{yr}^{-1}$ (Tillmann et al., 2000). Low estimates of water column primary production in eutrophic estuaries are common. Kocum et al. (2002) estimated water column primary production in the Colne Estuary at $8.9 \mathrm{gC} \mathrm{m}^{-2} \mathrm{yr}^{-1}$, but this low water column primary production did not affect secondary production of the ecosystem because the microphytobenthos primary production contributed between 25 and $1,200 \mathrm{gC} \mathrm{m}^{-2} \mathrm{yr}^{-1}$ (Thornton et al., 2002). For example, through resuspension, the microphytobenthos of the Ems Estuary which represented $22 \%$ to $60 \%$ of the total phytoplankton in the water column and $50 \%$ of the food available to filter feeders living on the tidal flats (De Jonge and van Beusekom, 1992, 1995). Average relative contributions of benthic microalgae were around $20 \%$ in MarennesOléron Bay (Guarini et al., 2004). The annual microphytobenthic production in MarennesOléron Bay has been estimated between 178 (Guarini, pers. comm.) and $372 \mathrm{gC} \mathrm{m}^{-2} \mathrm{yr}^{-1}$ (Leguerrier et al., 2003) and could be available to suspension feeders in the bay (Riera and Richard, 1996).

\section{Conclusion}

The present study allowed a $\mathrm{BZI}_{0}$ model of primary production to be calibrated and showed that water column primary production is light limited in Marennes-Oléron Bay. Using monthly means for TPM and $\mathrm{Chl} a$, the day-to-day variability in production estimates was caused by variability in irradiance, while seasonal variability in production was attributed to seasonal variations in irradiance, TPM and Chl $a$. Differences in the TPM between sites affected the estimates of primary production. On a tidal time scale of hours, variations in TPM could also be reasonably assumed to affect production. Water column 
primary production in the Marennes-Oléron Bay was estimated at $185 \mathrm{gC} \mathrm{m}^{-2} \mathrm{yr}^{-1}$ using the same mean TPM value applied over the entire bay. This value is in the low range of microphytobenthic production (372 $\mathrm{gC} \mathrm{m}^{-2} \mathrm{yr}^{-1}$, Leguerrier et al., 2003) and close to the mean of other primary production in intertidal ecosystems $\left(180 \mathrm{gC} \mathrm{m}^{-2} \mathrm{yr}^{-1}\right.$, Tillman et al., 2000). However, important changes of TPM (eg over the intertidal mudflats during flood and ebb tides) and associated changes in turbidity and thus light conditions in the water column, interacted to create spatial and temporal heterogeneity in production estimates for different areas of the Marennes-Oléron Bay. Water in the north and south of the bay are more productive and could become areas for offshore shellfish production.

\section{Acknowledgements}

We thank Jennifer Guarini and Helen Boudry for having corrected our manuscript, and Jean-Marc Guarini, Pierre Richard, Françoise Mornet and James Grizon for sampling and analytical assistance. The authors are also grateful to the two anonymous reviewers for their useful comments and suggestions. 


\section{References}

Aminot, A., Chaussepied, M., 1983. Manuel des analyses chimiques en milieu marin. CNEXO, 395 pp.

Bacher, C., 1989. Capacité trophique du bassin de Marennes-Oléron: couplage d'un modèle de transport particulaire et d'un modèle de croissance de l'huitre Crassostrea gigas / Trophic capacity of the Bay of Marennes-Oléron: coupling of particulate matter transport with a model of Crassostrea gigas growth. Aquatic Living Resources 2, 199-214. doi:10.1016/S09907440(03)00003-2

Bacher, C., Duarte, P., Ferreira, J.G., Héral, M., Raillard, O., 1998. Assessment and comparison of the Marennes-Oléron By (France) and Carlington Lough (Ireland) carrying capacity with ecosystem models. Aquatic Ecology 31, 379-394. doi:10.1023/A:1009925228308

Bacher, C., Sochard, S., Freissinet, C., Sauvaget, P., 2000. Vers une modélisation opérationnelle pour l'aménagement des zones côtières: l'exemple du bassin de MarennesOléron (France). La Houille Blanche 7/8, 66-73.

Barranguet, C., Kromkamp, J., Peene, J., 1998. Factors controlling primary production and photosynthetic characteristics of intertidal microphytobenthos. Marine Ecology Progress Series 173, 117-126.

Blanchard, G. F., Cariou-Le Gall, V., 1994. Photosynthetic characteristics of microphytobenthos in Marennes-Oleron Bay, France: preliminary results. Journal of Experimental Marine Biology and Ecology 182, 1-14. doi:10.1016/0022-0981(94)90207-0

Blanchard, G.F., Montagna, P.A., 1992. Photosynthetic response of natural assemblages of marine benthic microalgae to short- and long-term variations of incident irradiance in Baffin Bay, Texas. Journal of Phycology 28, 7-14.

Boutier, B., Chiffoleau, J.-F., Gonzalez, J.-L., Lazure, P., Auger, D., Truquet, I., 2000. Influences of the Gironde Estuary outputs on cadmium concentrations in the coastal waters: consequences on the Marennes-Oléron Bay (France). Oceanologica Acta 23, 745-757. doi:10.1016/S0399-1784(00)01119-1

Brunet, C., Lizon, F., 2003. Tidal and diel periodicities of size-fractionated phytoplankton pigment signatures at an offshore station in the southeastern English Channel. Estuarine, Coastal and Shelf Science 56, 833-843. doi:10.1016/S0272-7714(02)00323-2

Brush, M.J., Brawley, J.W., Nixon, S.W., Kremer, J.N., 2002. Modeling phytoplankton production: problems with the Eplley curve and an empirical alternative. Marine Ecology Progress Series 238, 31-45.

Cabeçadas, L., 1999. Phytoplankton production in the Tagus Estuary (Portugal). Oceanologica Acta 22, 205-214. doi:10.1016/S0399-1784(99)80046-2

Cloern, J. E., 1987. Turbidity as a control on phytoplankton biomass and productivity in estuaries. Continental Shelf Research 7, 1367-1381. doi:10.1016/0278-4343(87)90042-2 
Cole, B. E., Cloern, J. E., 1984. Significance of biomass and light availability to phytoplankton productivity in San Francisco Bay. Marine Ecology Progress Series 17, 15-24.

Cole, B.E., Cloern, J.E., 1987. An empirical model for estimating phytoplankton productivity in estuaries. Marine Ecology Progress Series 36, 299-305.

Côté, B., Platt, T., 1983. Day-to-day variations in the spring-summer photosynthetic parameters of coastal marine phytoplankton. Limnology and Oceanography 28, 320-344.

Dechambenoy C., Pontier L., Sirou F., Vouvé J., 1977. Apport de la thermographie infrarouge aéroportée à la connaissance $\mathrm{d}$ la dynamique superficielle des estuaires (système CharenteSeudre-anse de l'Aiguillon). Comptes rendus de l'Académie des Sciences de Paris, série D 284,1269-1272.

de Jonge, V., van Beusekom, J., 1992. Contribution of resuspended microphytobenthos to total phytoplankton in the Ems Estuary and its possible role for grazers. Netherlands Journal of Sea Research 30, 91-105.

de Jonge, V.N., van Beusekom, J.E.E., 1995. Wind- and tide-induced resuspension of sediment and microphytobenthos from tidal flats in the Ems Estuary. Limnology and Oceanography 40, 766-778.

Demers, S., Legendre, L., 1979. Effets des marées sur la variation circadienne de la capacité photosynthétique du phytoplancton du Saint-Laurent. Journal of Experimental Marine Biology and Ecology 39, 97-99. doi:10.1016/0022-0981(79)90007-8

Dortch, Q., Whitledge, T., 1992. Does nitrogen or silicon limit phytoplankton production in the Mississippi River plume and nearby regions? Continental Shelf Research 12, 1293-1309. doi:10.1016/0278-4343(92)90065-R

Fisher, T., Harding, L., Stanley, D., Ward, L., 1988. Phytoplankton, nutrients, and turbidity in the Chesapeake, Delaware, and Hudson estuaries. Estuarine, Coastal and Shelf Science 27, 61-93. doi:10.1016/0272-7714(88)90032-7

Forbes, J.R., Denman, K.L., Mackas, D.L., 1986. Determinations of photosynthetic capacity in coastal marine phytoplankton: effects of assay irradiance and variability of photosynthetic parameters. Marine Ecology Progress Series 32, 181-191.

Fréchette, M., Legendre, L., 1982. Phytoplankton photosynthetic response to light in an internal tide dominated environment. Estuaries 5, 287-293.

Gallegos, C., Platt, T., 1985. Vertical advection of phytoplankton and productivity estimates: A dimensional analysis. Marine Ecology Progress Series 26, 125-134.

Geider, R., MacIntyre, H., Kana, T., 1997. Dynamic model of phytoplankton growth and acclimation: responses of the balanced growth rate and the chlorophyll a:carbon ratio to light, nutrient-limitation and temperature. Marine Ecology Progress Series 148, 187-200.

Guarini, J.-M., Gros, P., Blanchard, G., Richard, P., Fillon, A., 2004. Benthic contribution to pelagic communities in two semi-enclosed, European-type littoral ecosystems (Marennes- 
Oléron Bay and Aiguillon Bay, France). Journal of Sea Research 52, 241-258. doi: 10.1016/j.seares.2004.04.003

Harding, L. Jr., Mallonee, M., Perry, E., 2002. Toward a predictive understanding of primary productivity in a temperate, partially stratified estuary. Estuarine, Coastal and Shelf Science 55, 437-463. doi:10.1006/ecss.2001.0917

Harrison, W., Platt, T., 1980. Variations in assimilation number of coastal marine phytoplankton: effects of environmental co-variates. Journal of Plankton Research 2, 249-260.

Hartig, P., Wolfstein, K., Lippemeier, S., Colijn, F., 1998. Photosynthetic activity of natural microphytobenthos populations measured by fluorescence (PAM) and 14C-tracer methods: a comparaison. Marine Ecology Progress Series 166, 53-62.

Heip, C. H. R., Goosen, N. K., Herman, P. M. J., Kromkamp, J., Middelburg, J. J., Soetaert, K., 1995. Production and consumption of biological particles in temperate tidal estuaries. Oceanography and Marine Biology 33, 1-149.

Héral, M., Razet, D., Deslou-Paoli, J.-M., Berthomé, J.-P., Garnier, J., 1983. Caractéristiques saisonnières de l'hydrobiologie du complexe estuarien de Marennes-Oléron (France). Revue de travaux de l'institut des pêches maritimes 46, 97-119.

Héral, M., Razet, D., Deslou-Paoli, J.-M., Manaud, F., Truquet, I., Garnier, J., 1984. Hydrobiologie du bassin de Marennes -Oléron. Résultats du réseau national d'observation: 1977 à 1981. Annales de la société de sciences naturelles de Charente -Maritime 7, 259-277.

Jassby, A.D., Platt, T., 1976. Mathematical formulation of the relationship between photosynthesis and light for phytoplankton. Limnology and Oceanography 21, 540-547.

Joint, I., Pomroy, A., 1993. Phytoplankton biomass and production in the southern North Sea. Marine Ecology Progress Series 99, 169-182.

Kocum, E., Underwood, G.J.C., Nedwell, D.B., 2002. Simultaneous measurement of phytoplanktonic primary production, nutrient and light availability along a turbid, eutrophic UK east coast estuary (the Colne Estuary). Marine Ecology Progress Series 231, 1-12.

Kromkamp, J., Peene, J., 1995. Possibility of net phytoplankton primary production in the turbid Chelde Estuary (SW Netherlands). Marine Ecology Progress Series 121, 249-259.

Leguerrier, D., Niquil, N., Boileau, N., Rzeznik, J., Sauriau, P.-G., Le Moine O., Bacher, C., 2003. Numerical analysis of the food web of an intertidal mudflat ecosystem on the Atlantic coast of France. Marine Ecology Progress Series 246, 17-37.

Lewis, M.L., Smith, J.C., 1983. A small volume, short-incubation time method for measurement of photosynthesis as a function of incident irradiance. Marine Ecology Progress Series 13, 99-102.

Lucas, L. V., Koseff, J. R., Monismith, S. G., Cloern, J. E., Thompson, J. K., 1999. Processes governing phytoplankton blooms in estuaries. II: The role of horizontal transport. Marine Ecology Progress Series 187, 17-30. 
MacCaull, W., Platt, T., 1977. Diel variations in the photosynthetic parameters of coastal marine plankton. Limnology and Oceanography 22, 723-731.

MacIntyre, H., Kana, T., Geider, R., 2000. The effect of water motion on short-term rates of photosynthesis by marine phytoplankton. Trends in Plant Science 5, 12-17. doi:10.1016/S1360-1385(99)01504-6

Malone, T., Crocker, L., Pike, S., Wendler, B., 1988. Influences of river flow on the dynamics of phytoplankton production in a partially stratified estuary. Marine Ecology Progress Series $48,235-249$.

Mallin, M., Paerl, H., 1992. Effects of variable irradiance on phytoplankton productivity in shallow estuaries. Limnology and Oceanography 37, 54-62.

Ménesguen, A., Guillaud, J.-F., Aminot, A., Hoch, T., 1995. Modelling the eutrophication process in a river plume: the Seine case study (France). Ophelia 42, 205-225.

Migné, A., Spilmont, N., Davoult D., 2004. In situ measurements of benthic primary production during emersion: seasonal variations and annual production in the Bay of Somme (eastern English Channel, France). Continental Shelf Research 24, 1437-1449. doi:10.1016/j.csr.2004.06.002

Montani, S., Magni, P., Abe, N., 2003. Seasonal and interannual patterns of intertidal microphytobenthos in combination with laboratory and areal production estimates. Marine Ecology Progress Series 249, 79-91.

Oviatt, C., Keller, A., Reed, L., 2002. Annual primary production in Narragansett Bay with no bay-wide winter-spring phytoplankton bloom. Estuarine, Coastal and Shelf Science 54, 1013 1026. doi:10.1006/ecss.2001.0872

Parsons, T.R., Maita, Y., Lalli, C.M., 1984. A manual of chemical and biological methods for seawater analysis. Pergamon Press, Oxford, 173 pp.

Pennock, J.R., Sharp, J.H., 1986. Phytoplankton production in the Delaware Estuary: temporal and spatial variability. Marine Ecology Progress Series 34, 143-155.

Platt, T., 1975. Analysis of the importance of spatial and temporal heterogeneity in the estimation of annual production by phytoplankton in a small enriched, marine basin. Journal of Experimental Marine Biology and Ecology 18, 99-109. doi:10.1016/0022-0981(75)900672

Raillard, O., Ménesguen, A., 1994. An ecosystem box model for estimating the carrying capacity of a macrotidal shellfish system. Marine Ecology Progress Series 115, 117-130.

Ravail, B., 1993. Incidences du débit de la Charente sur la capacié biotique du bassin ostréicole de Marennes-Oléron. Thèse de doctorat: Université de Nantes. 254 pp.

Ravail, B., Héral, M., Maestrini, S., Robert, J. M., 1988. Incidence du débit de la Charente sur la capacité biotique du bassin ostréicole de Marennes-Oléron / Effect of the flow from the 
Charente River on the biotic capacity of the oyster beds in the Marennes-Oléron Bay. Journal de Recherche Océanographique 13, 48-52.

Riera, R., Richard, P., 1996. Isotopic determination of Food Sources of Crassostrea gigas along a trophic gradient in the estuarine bay of Marennes-Oleron. Estuarine, Coastal and Shelf Science 42, 347-360. doi:10.1006/ecss.1996.0023

Sakshaug, E., Bricaud, A., Dandonneau, Y., Falkowski, P., Kiefer, D., Legendre, L., Morel, A., Parslow, J., Takahashi, M., 1997. Parameters of photosynthesis: definitions, theory and interpretation of results. Journal of Plankton Research 19, 1637-1670.

Shaw, P.J., Purdie, D.A., 2001. Phytoplankton photosynthesis-irradiance parameters in the near-shore UK coastal waters of the North Sea: temporal variation and environmental control. Marine Ecology Progress Series 216, 83-94.

Soletchnik, P., Faury, N., Razet, D., Goulletquer, P., 1998. Hydrobiology of the MarennesOléron Bay. Seasonal indices and analysis of trends from 1978 to 1995 . Hydrobiologia 386, 131-146. doi:10.1023/A:1003511815728

Sournia, A., 1974. Circadian periodicities in natural populations of marine phytoplankton. Advances in Marine Biology 12, 325-389.

Strickland, J.D.H., Parsons T.R., 1972. A pratical hand book of seawater analysis, Fisheries Research Board of Canada. Bulletin 167 (Second Edition). Ottawa.

Thornton, D., Dong, L., Underwood, G., Nedwell, D., 2002. Factors affecting microphytobenthic biomass, species composition and production in the Colne Estuary (UK). Aquatic Microbial Ecology 27, 285-300.

Tillmann, U., Heesse, K., Colijn, F., 2000. Planktonic primary production in the German Wadden Sea. Journal of Plankton Research 22, 1253-1276.

Wolfstein, K., Colijn, F., Doerffer, R., 2000. Seasonal dynamics of microphytobenthos biomass and photosynthetic characteristics in the Northern German Wadden Sea, obtained by the photosynthetic light dispensation system. Estuarine, Coastal and Shelf Science 51, 651662. doi:10.1006/ecss.2000.0702 


\section{Tables}

Table 1. Coefficient of variation (\%) for productivity estimates for each sampling date and the spatial, seasonal and total variation.

\begin{tabular}{c|c|c|c|c|c|c|c}
\cline { 2 - 8 } & Site 1 & Site 2 & Site 3 & Site 4 & Site 5 & Site 6 & Spatial \\
\hline Fall & 24 & 119 & 44 & 31 & 59 & 40 & 38 \\
\hline Winter & 57 & 64 & 34 & 62 & 57 & 34 & 36 \\
\hline Summer & 40 & 11 & 39 & 50 & 62 & 69 & 62 \\
\hline Seasonal & 54 & 52 & 64 & 81 & 81 & 126 & total:140 \\
\hline
\end{tabular}

Table 2. Estimates of annual primary production $\left(\mathrm{gC} \mathrm{m}^{-2} \mathrm{yr}^{-1}\right)$ for various estuaries and bays worldwide (adapted from Tillmann et al., 2000 and Heip et al., 1995)

\begin{tabular}{|c|c|c|c|}
\hline Type & Region & $\begin{array}{c}\text { Annual } \\
\text { production }\end{array}$ & Reference \\
\hline \multirow{14}{*}{ 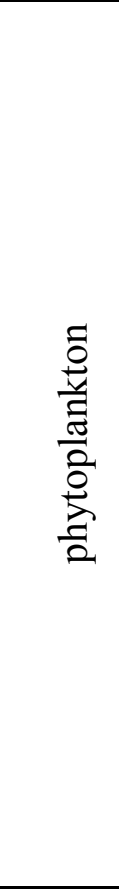 } & Europe & & \\
\hline & $\begin{array}{c}\text { Marennes-Oléron Bay, } \\
\text { France }\end{array}$ & 185 & This study \\
\hline & $\begin{array}{c}\text { Estuarine part of } \\
\text { Northfrisian Wadden Sea, } \\
\text { Germany }\end{array}$ & $127-177$ & Tillmann et al., 2000 \\
\hline & Tagus estuary, Portugal & 26 & Cabeçadas, 1999 \\
\hline & Bristol Channel, UK & $7-165$ & Joint and Pomroy, 1981 \\
\hline & $\begin{array}{l}\text { Westerschelde, } \\
\text { Netherlands }\end{array}$ & $100-300$ & Kromkamp and Peene, 1995 \\
\hline & Colne Estuary, UK & 8.9 & Kocum et al., 2002 \\
\hline & USA & & \\
\hline & Delaware Estuary & 307 & Pennock and Sharp, 1986 \\
\hline & Narragansett Bay & 323 & Oviatt et al., 2002 \\
\hline & San Francisco Bay & $6-418$ & Cole and Cloern, 1984 \\
\hline & Hudson River & $70-240$ & Cole et al., 1992 \\
\hline & Chesapeake Bay & $324-569$ & Malone et al., 1988 \\
\hline & Chesapeake Bay & 570 & Harding et al., 2000 \\
\hline \multirow{8}{*}{ 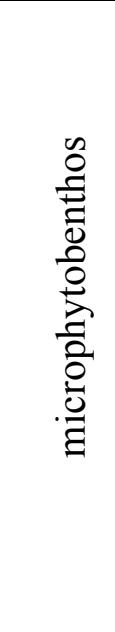 } & $\begin{array}{l}\text { Marennes-Oléron } \\
\text { Bay,France }\end{array}$ & 372 & Leguerrier et al., 2003 \\
\hline & $\begin{array}{l}\text { Marennes-Oléron } \\
\text { Bay,France }\end{array}$ & 178 & Guarini, unpubl data \\
\hline & Bay of Somme, France ${ }^{b}$ & 147 & Migné et al., 2004 \\
\hline & European estuaries & $60-314$ & Heip et al., 1995 \\
\hline & $\begin{array}{l}\text { Intertidal flats of } \\
\text { Westerschelde, } \\
\text { Netherlands }\end{array}$ & $7-53$ & Barranguet et al., 1998 \\
\hline & Colne Estuary, UK & $25-1199$ & Thornton et al., 2002 \\
\hline & North American estuaries & $29-226$ & Heip et al., 1995 \\
\hline & $\begin{array}{l}\text { Estuarine flat of Seto } \\
\text { Inland Sea, Japan }{ }^{c}\end{array}$ & 434 & Montani et al., 2003 \\
\hline
\end{tabular}

\footnotetext{
${ }^{\mathrm{a}}$ : Brouage mudflat $-{ }^{\mathrm{b}}$ : sand and muddy-sand $-{ }^{\mathrm{c}}$ : sand
} 
Figure legends

Figure 1. Sampling site locations in Marennes-Oléron Bay, France. Sites 1, 2, 3', 4 and $6(\bullet)$ were sampled during 2001 and 2002 for this study. Sites 1, 2, 5, $6(\bullet)$ and 3' ( $\mathbf{\Delta})$ were also sampled bi-monthly for the RAZLEC water quality database. Light gray areas indicate the intertidal mudflat areas. The black rectangle indicates the zone of primary production estimation.

Figure 2. Evolution of Chl $a(\mathrm{~A})$ and phosphate concentrations (B) (note scale change for winter data) and light attenuation coefficient $\mathrm{k}(\mathrm{C})$, in surface (solid lines) and bottom water (dashed lines) samples, during each survey.

Figure 3. Example of a P-E curve. Sample data are plotted with the adjusted model of Jassby and Platt (1976) for surface water (model S), bottom water (model B) and the adjusted model for all data (model $\mathrm{S}+\mathrm{B}$ ).

Figure 4. Change in the photosynthetic parameters $\mathrm{P}^{\mathrm{B}}{ }_{\mathrm{m}}(\mathrm{A}), \alpha^{\mathrm{B}}(\mathrm{B})$ and in the Em/Ek ratio $(\mathrm{C})$ in surface water (solid lines) and bottom water (dashed lines) samples, during each survey. Error bars for (A) and (B) are for model estimates.

Figure 5. Estimated change in primary production per unit area of surface water (solid lines) or bottom water (dashed lines) samples, during each survey.

Figure 6. The estimated daily (A, at sites 1 and 2) and monthly (B, at sites 1, 2, 3, 5 and 6) primary production per unit area in 2001 and 2002. 
Figure 1. Sampling site locations in Marennes-Oléron Bay, France. Sites 1, 2, 3', 4 and $6(\bullet)$

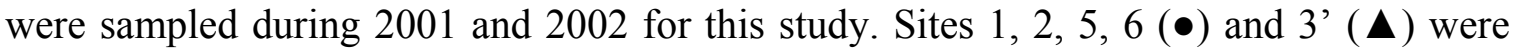
also sampled bi-monthly for the RAZLEC water quality database. Light gray areas indicate the intertidal mudflat areas. The black rectangle indicates the zone of primary production estimation.

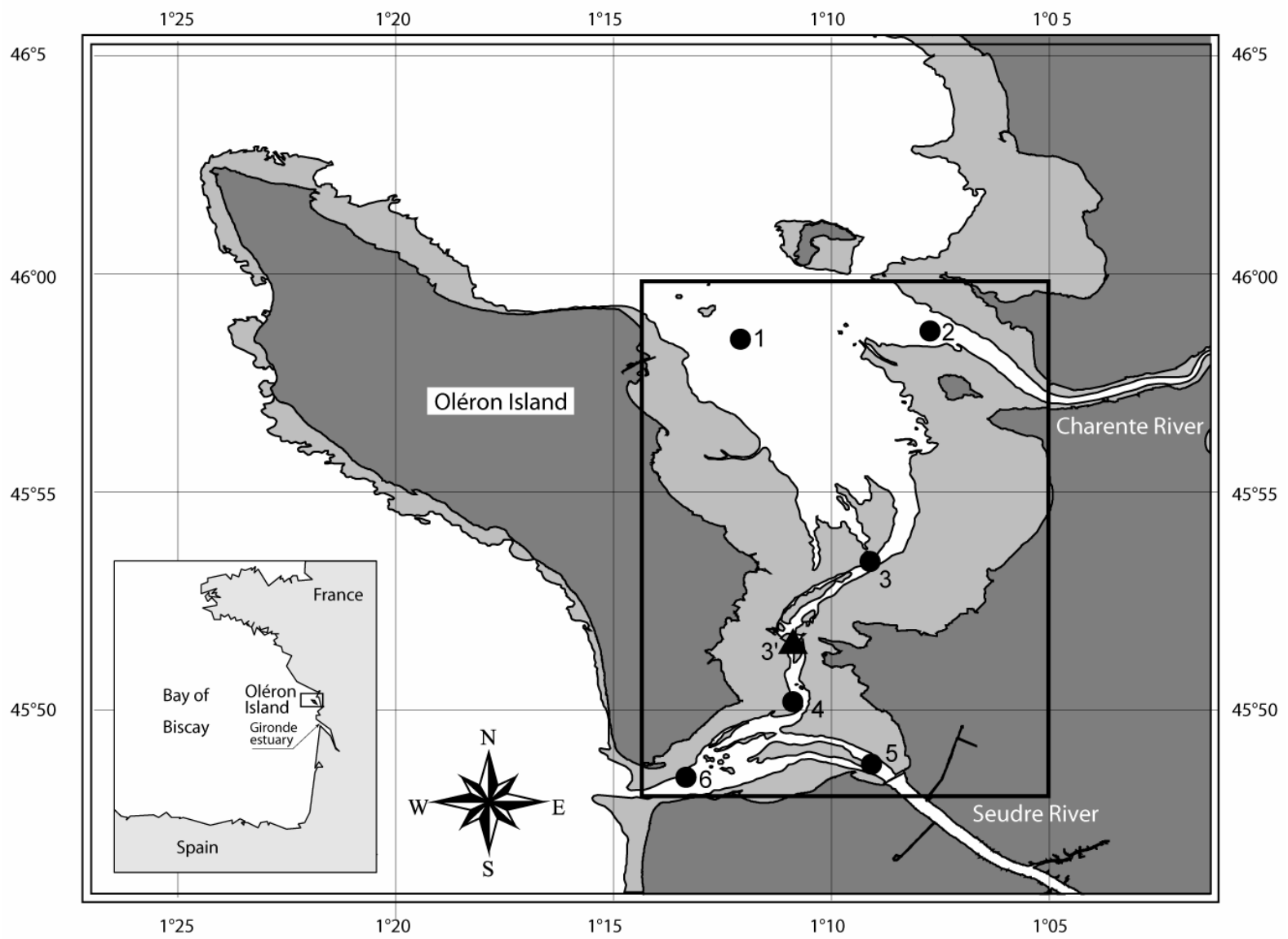


Figure 2. Evolution of Chl $a(\mathrm{~A})$ and phosphate concentrations (B) (note scale change for winter data) and light attenuation coefficient $\mathrm{k}(\mathrm{C})$, in surface (solid lines) and bottom water (dashed lines) samples, during each survey.
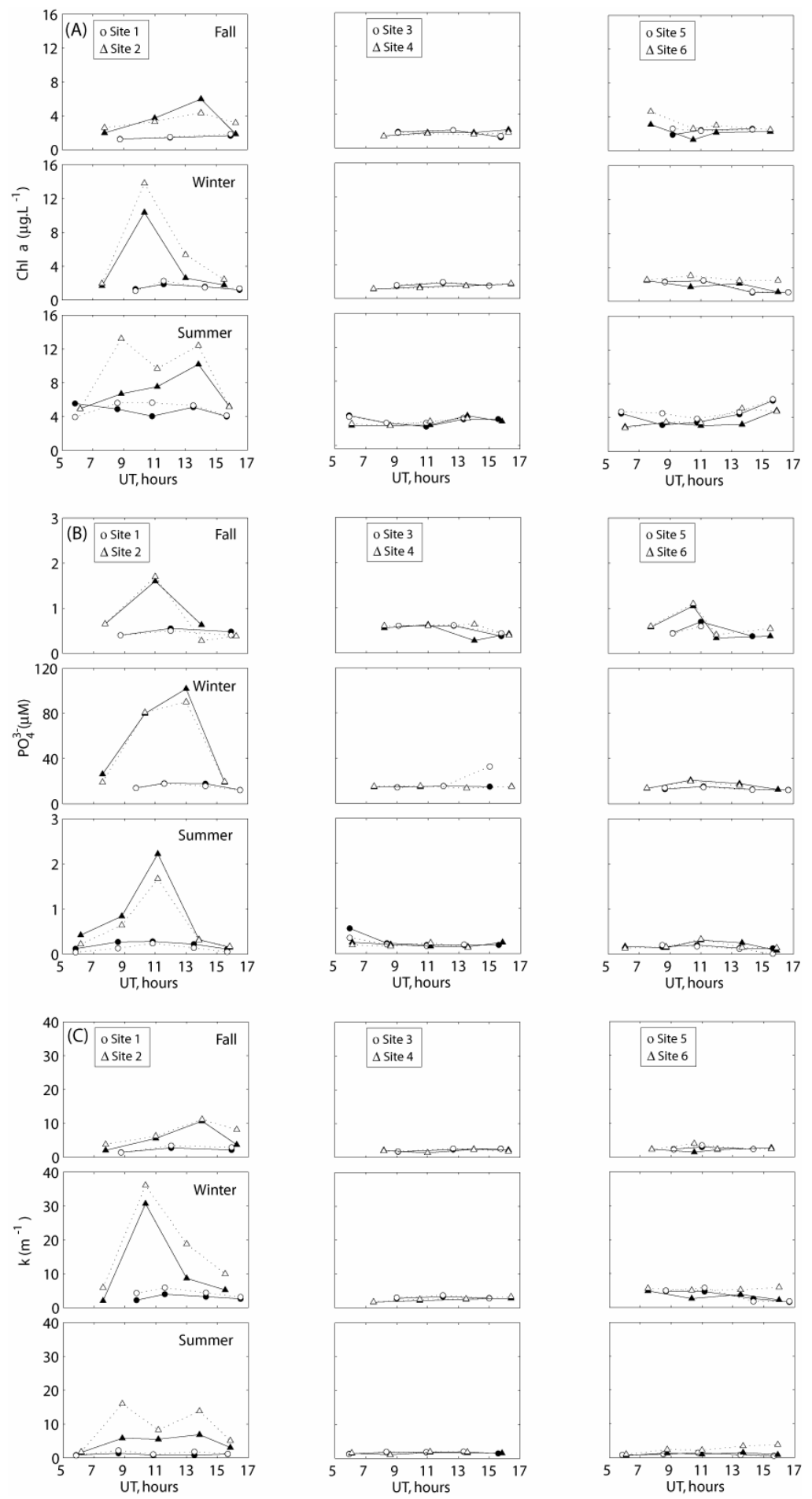
Figure 3. Example of a P-E curve. Sample data are plotted with the adjusted model of Jassby and Platt (1976) for surface water (model S), bottom water (model B) and the adjusted model for all data (model $\mathrm{S}+\mathrm{B})$.

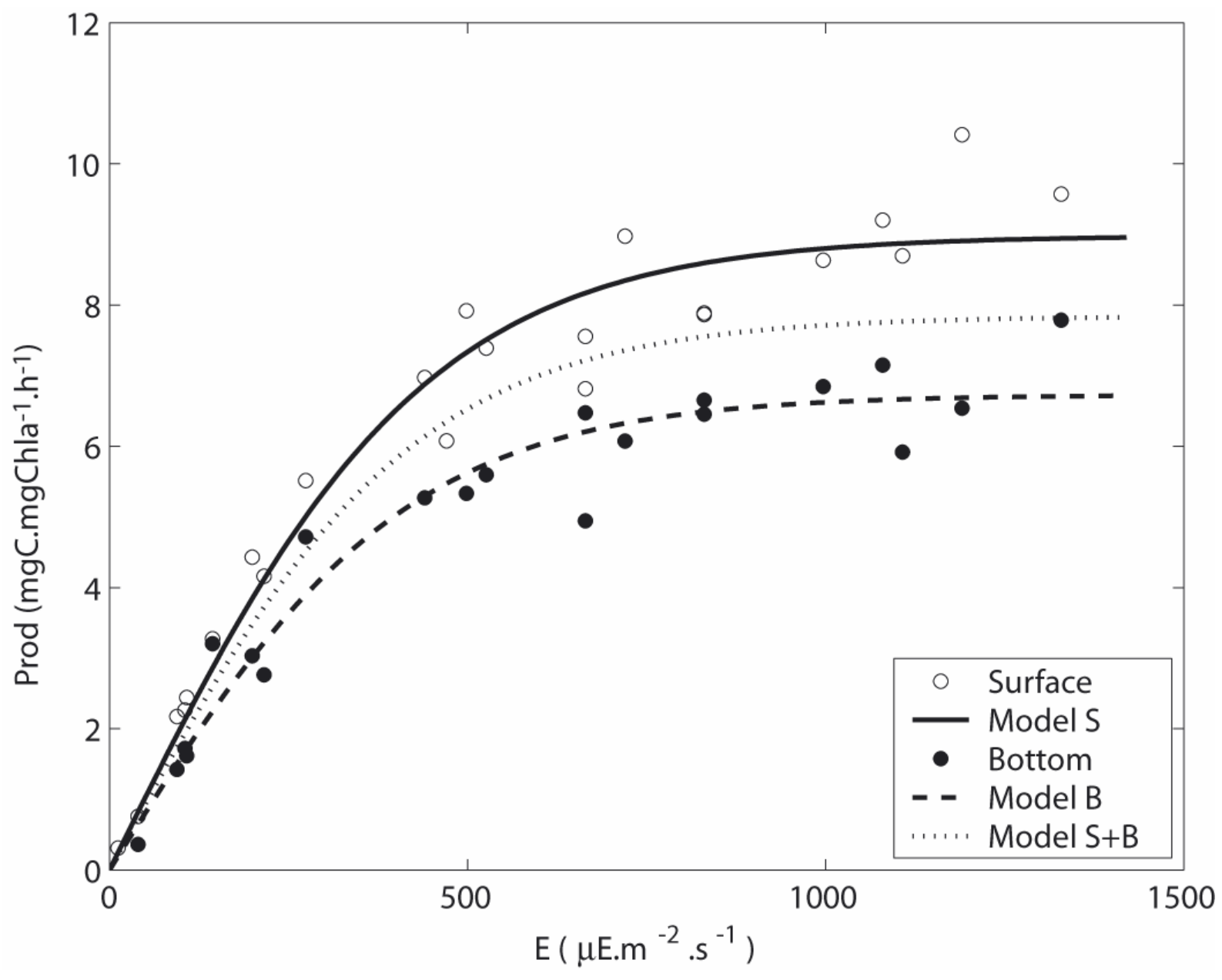


Figure 4. Change in the photosynthetic parameters $\mathrm{P}^{\mathrm{B}}{ }_{\mathrm{m}}(\mathrm{A}), \alpha^{\mathrm{B}}(\mathrm{B})$ and in the Em/Ek ratio $(\mathrm{C})$ in surface water (solid lines) and bottom water (dashed lines) samples, during each survey. Error bars for (A) and (B) are for model estimates.
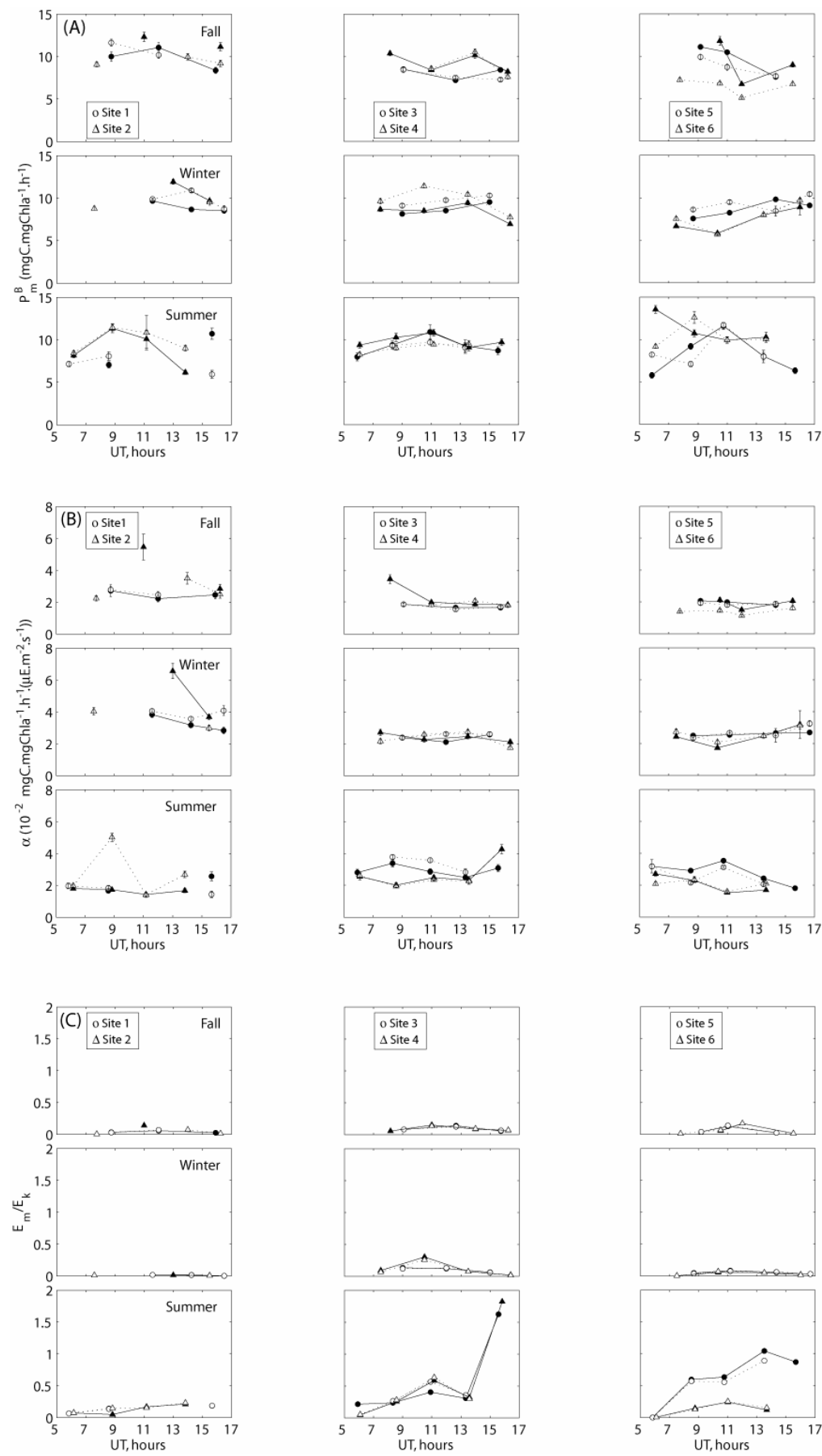
Figure 5. Estimated change in primary production per unit area of surface water (solid lines) or bottom water (dashed lines) samples, during each survey.
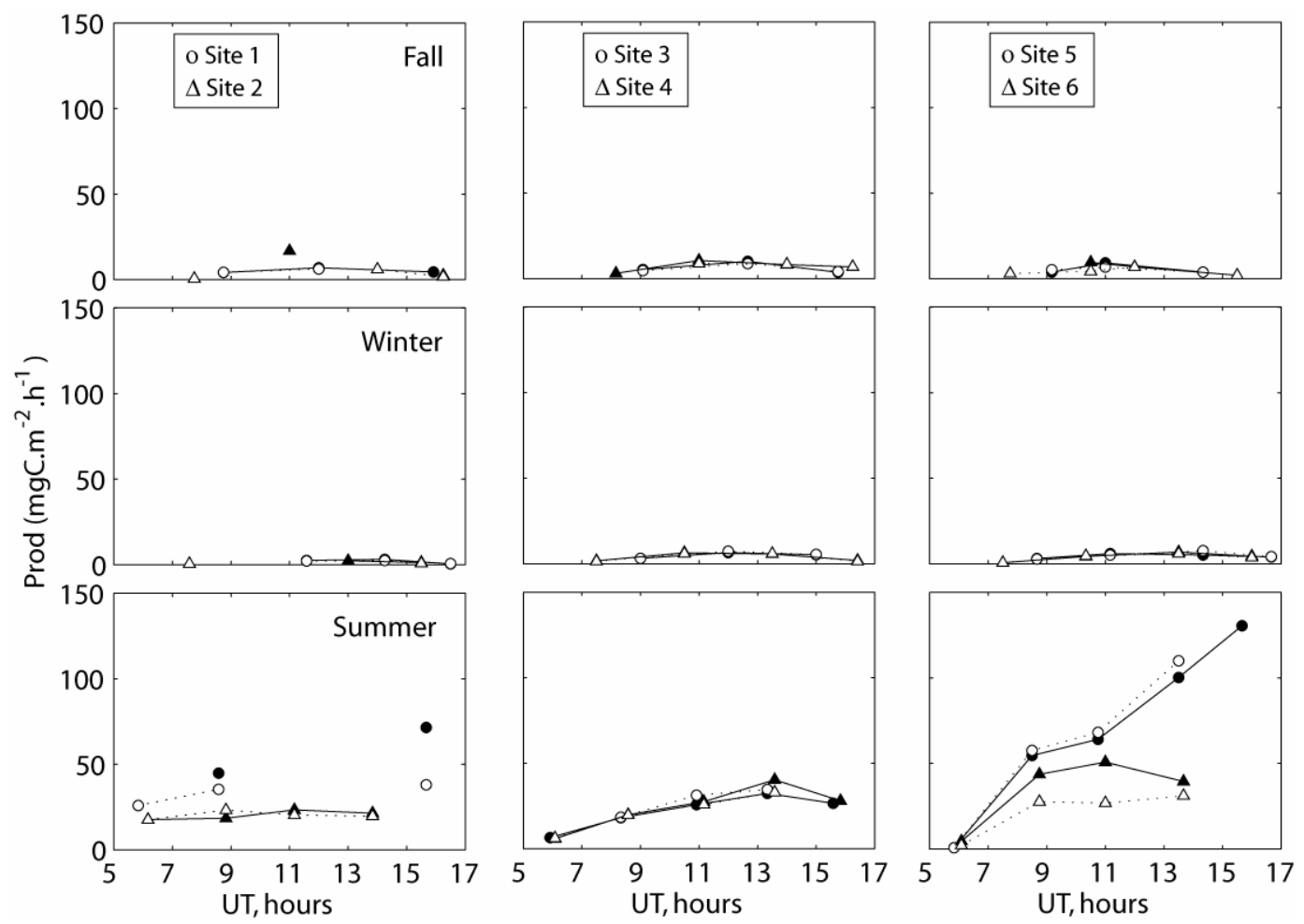
Figure 6. The estimated daily (A, at sites 1 and 2) and monthly (B, at sites 1, 2, 3', 5 and 6) primary production per unit area in 2001 and 2002.
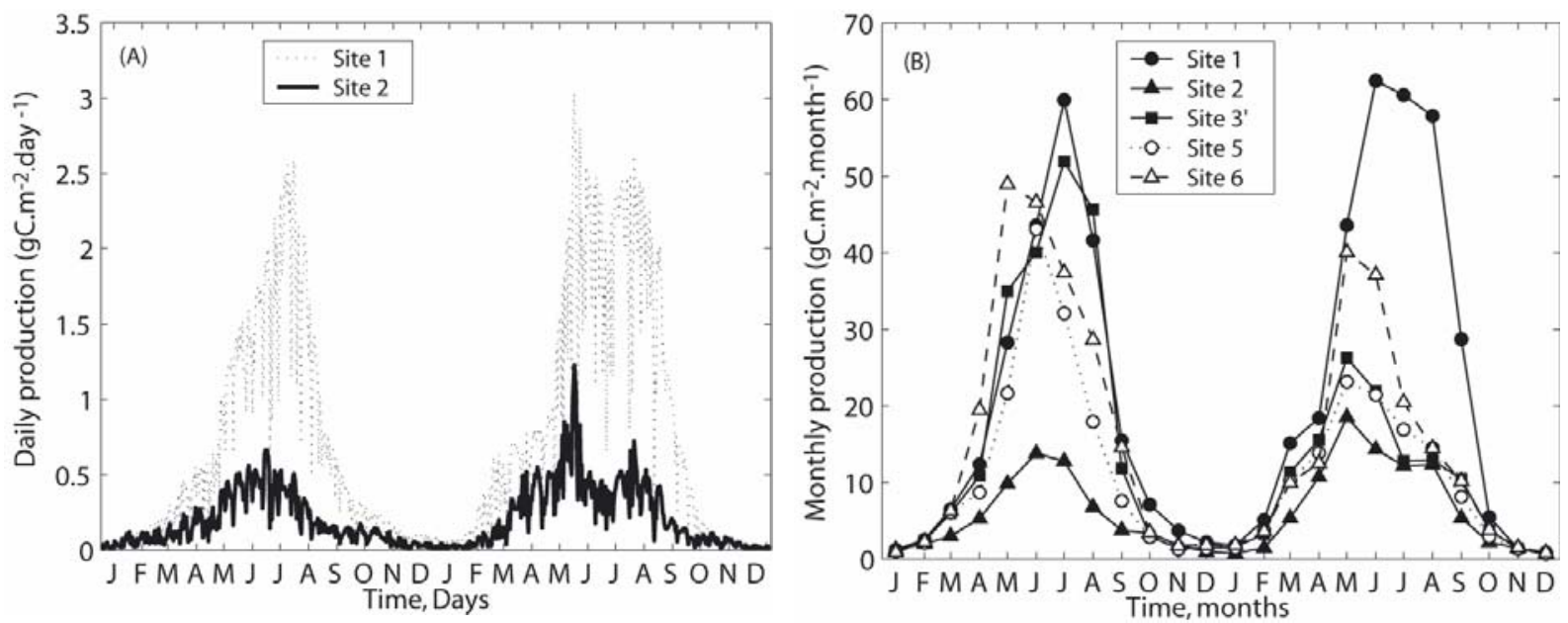